\title{
SIFAT KEPUTUSAN BADAN PENGAWAS PEMILIHAN UMUM DALAM PENYELESAIAN SENGKETA PEMILIHAN UMUM
}

\author{
MIA SIRATNI \\ Sekolah Tinggi Ilmu Hukum Padang \\ miasiratni@gmail.com
}

\begin{abstract}
Bawaslu resolves by deliberation by bringing together the disputing parties to then take a final and binding decision. The final and binding nature of this Bawaslu decision does not apply to certain disputes, namely the dispute over the verification of political parties participating in the General Election and the determination of the final list of candidates for the election of members of the DPR, DPD, and DPRD. The existence of these two characteristics of Bawaslu's decision then led to different interpretations between Bawaslu and the KPU. The formulation of the problem, namely 1). The authority of Bawaslu in resolving election disputes regarding the task of supervising the implementation of elections, 2). The nature of Bawaslu's decisions in resolving election disputes. The research method used in this paper is normative juridical, namely an approach to legal norms or applicable laws and regulations, theories, and history. From the discussion of the problem, it is concluded that a decision that is final and binding is given to Bawaslu by law in order to end election disputes so that it will show the role of Bawaslu as a unified function of organizing elections. Meanwhile, exceptions to the nature of final and binding decisions on political party verification disputes and the permanent list of candidates for members of the DPR, DPD, and DPRD indicate that Bawaslu is not a judicial institution, so it cannot decide disputes related to constitutional rights as election participants.
\end{abstract}

Keywords: Nature, Decision, Bawaslu, Election.

Abstrak: Bawaslu menyelesaikan secara musyawarah dengan mempertemukan para pihak yang bersengketa untuk kemudian diambil keputusan yang bersifat final dan mengikat. Sifat final dan mengikat dari keputusan Bawaslu ini tidak berlaku bagi sengketa tertentu, yaitu sengketa verifikasi partai politik peserta Pemilu dan penetapan daftar calon tetap Pemilu anggota DPR, DPD, dan DPRD. Adanya dua sifat putusan Bawaslu tersebut kemudian menimbulkan penafsiran yang berbeda antara Bawaslu dan KPU. Adapun rumusan masalah, yaitu 1). Kewenangan Bawaslu dalam penyelesaian sengketa Pemilu terhadap tugas pengawasan penyelenggaraan Pemilu, 2). Sifat keputusan Bawaslu dalam penyelesaian sengketa Pemilu. Metode penelitian yang digunakan dalam penulisan ini adalah yuridis normatif, yakni pendekatan terhadap norma hukum atau peraturan perundang-undangan yang berlaku, teori-teori, dan sejarah. Dari pembahasan permasalahan disimpulkan bahwa Keputusan yang bersifat final dan mengikat diberikan kepada Bawaslu oleh undangundang dalam rangka mengakhiri sengketa Pemilu sehingga akan menunjukkan peran Bawaslu sebagai satu kesatuan fungsi penyelenggaraan Pemilu. Sementara itu, pengecualian terhadap sifat keputusan final dan mengikat pada sengketa verifikasi partai politik dan daftar calon tetap anggota DPR, DPD, dan DPRD menunjukkan bahwa Bawaslu bukanlah lembaga peradilan, sehingga tidak dapat memutus sengketa yang berkaitan dengan hak konstitusional sebagai peserta Pemilu.

Kata Kunci: Sifat, Keputusan, Bawaslu, Pemilu. 


\section{A. Pendahuluan}

Keberadaan KPU dan Bawaslu sebagai satu kesatuan fungsi penyelenggaraan Pemilu dapat diartikan bahwa keberhasilan penyelenggaraan Pemilu tidak saja akan ditentukan oleh kemampuan KPU dalam melaksanakan semua tahap Pemilu, tetapi juga oleh Bawaslu. Melalui tugas pengawasan dari Bawaslu, diharapkan Pemilu bisa terlaksana dengan baik dan sesuai dengan asasnya, yaitu langsung, umum, bebas, rahasia, serta jujur dan adil. Masing- masing tugas dan kewenangan yang dimiliki oleh kedua lembaga ini menunjukkan dua hal yang saling melengkapi dan saling menguatkan demi terselenggaranya Pemilu yang berkualitas.

Penyelenggaraan Pemilu salah satunya diadakan untuk memilih anggota DPR,

DPD, dan DPRD. ${ }^{6}$ Dalam penyelenggaraan Pemilu ini melibatkan banyak pihak karena diikuti oleh partai-partai politik dan orang-orang yang akan dipilih dari partai politik tersebut. Penyelenggara Pemilu terutama KPU sebagai pelaksana Pemilu akan dihadapkan kepada persoalan-persoalan yang berhubungan dengan banyak pihak tersebut dan akan menjadi suatu tantangan terhadap kemandirian serta independensi KPU. Sejalan dengan persoalan tersebut, maka peran dan tanggung jawab Bawaslu semakin diharapkan untuk mengawasi berjalannya Pemilu.

Pemilu selain sebagai perwujudan kedaulatan rakyat juga merupakan arena kompetisi bagi partai politik untuk melihat sejauh mana mereka telah melaksanakan fungsi dan perannya. Didalam sebuah kompetisi sudah dapat dimaklumi bahwa akan ada persaingan-persaingan untuk menjadi pemenang. Dengan sistem Pemilu yang ada sekarang ini dan pelaksanaan Pemilu yang diikuti oleh banyak orang dan partai politik, menjadikan Pemilu sangat rawan terjadinya pelanggaran dan penyimpangan. Setiap orang yang ikut sebagai peserta Pemilu untuk dipilih serta partai politik peserta Pemilu memiliki keinginan yang kuat agar menjadi pemenang dalam penyelenggaraan Pemilu tersebut. Kondisi seperti ini memerlukan suatu pengawasan dari sebuah lembaga yang dijamin dengan suatu undang-undang agar Pemilu tersebut berjalan sesuai aturan yang ada (Sukriono, 2009).

Mengingat fungsi Bawaslu yang sangat dibutuhkan, maka Bawaslu ditetapkan sebagai penyelenggara Pemilu yang bersifat tetap dan mempunyai kewenangan mengawasi jalannya Pemilu. Hal ini sesuai dengan pendapat bahwa eksistensi lembaga pengawas Pemilu akan semakin lemah apabila tidak mempunyai kewenangan yang maksimal, sehingga berakibat pada kurang maksimalnya kinerja Bawaslu tersebut. Kelemahan-kelemahan yang dimiliki oleh Bawaslu akibat keterbatasan tugas dan kewenangan dalam mengawasi penyelenggaraan Pemilu pada akhirnya akan dapat membahayakan perjalanan demokrasi di Indonesia (Firmanzah, 2010). Dalam Undang-Undang Nomor 15 Tahun 2011 Tentang Penyelenggara Pemilu disebutkan bahwa Bawaslu sebagai penyelenggara Pemilu memiliki tugas mengawasi penyelenggaraan Pemilu.Tugas pengawasan penyelenggaraan Pemilu telah dimiliki dan dimulai sejak tahap persiapan penyelenggaraan hingga tahap pelaksanaan Pemilu. Kewenangan ini sejalan dengan tugas dan agenda yang dilaksanakan oleh KPU dalam penyelenggaraan Pemilu. Hal ini menunjukkan adanya upaya untuk memaksimalkan kewenangan Bawaslu dalam mencapai Pemilu yang berkualitas yang sesuai dengan asas langsung, umum, bebas, rahasia, serta jujur dan adil.

Dalam menjalankan tugas pengawasan penyelenggaraan Pemilu, Bawaslu diberikan kewenangan dalam penyelesaian sengketa Pemilu Hal ini dipertegas lagi dalam Pasal 258 Ayat (1) Undang-Undang Nomor 8 Tahun 2012 Tentang Pemilu Anggota DPR, DPD, dan DPRD yang menyebutkan bahwa "Bawaslu berwenang 
dalam penyelesaian sengketa Pemilu”. Adanya pengaturan tentang kewenangan ini menjadi landasan hukum bagi Bawaslu, sehingga setiap sengketa yang terjadi dalam pelaksanaan Pemilu dapat diselesaikan melalui Bawaslu. Sengketa Pemilu yang dimaksud oleh undang-undang tersebut adalah sengketa yang terjadi antar peserta Pemilu dan sengketa antara peserta Pemilu dengan penyelenggara Pemilu sebagai akibat dikeluarkannya keputusan KPU, KPU Provinsi, dan KPU Kabupaten/Kota.11 Bentuk sengketa Pemilu tersebut dapat berupa sengketa terkait verifikasi partai politik peserta Pemilu dan daftar calon tetap anggota DPR, DPD, dan DPRD Provinsi, Kabupaten/kota.

Kemungkinan terjadinya sengketa Pemilu bisa terjadi karena setiap mekanisme dan tahapan yang dilalui oleh peserta Pemilu seringkali berkaitan dengan keputusan atau ketetapan yang dikeluarkan oleh KPU. Tahap verifikasi partai politik merupakan salah satu tahapan yang berpotensi menimbulkan sengketa. Tahap ini merupakan salah satu fase yang paling krusial dan menegangkan. Sebab, di fase ini, KPU menentukan nasib parpol untuk bisa atau tidaknya menjadi peserta Pemilu. Keputusan KPU terkait hasil verifikasi partai politik peserta Pemilu kemudian akan menimbulkan suatu permasalahan antara peserta Pemilu dengan KPU.

Perbedaan pendapat tentang persoalan yang berkaitan dengan sifat keputusan Bawaslu tersebut diatas tentu berdasarkan kepada pendapat dan penafsiran masing-masing terhadap pengertian sifat final dan mengikat keputusan Bawaslu. Sikap memaksakan kebenaran pendapat atau penafsiran masing-masing terhadap norma yang mengatur tentang penyelesaian sengketa Pemilu ini akan mengurangi kualitas dan integritas kedua lembaga (KPU dan Bawaslu) sebagai penyelenggara Pemilu. Sehingga hal tersebut akan melahirkan wacana dan tanggapan yang tidak baik dari masyarakat yang meragukan akan kemampuan kedua lembaga ini dalam menjamin terselenggaranya Pemilu yang berkualitas.

\section{B. Metodologi Penelitian}

Jenis penelitian yang digunakan adalah penelitian hukum normatif, yaitu penelitian yang dilakukan dengan cara meneliti Bahan Pustaka atau Data Sekunder. ${ }^{14}$ Dari Data Sekunder ini kemudian dilakukan rekonstruksi sehingga menjadi suatu rangkaian hasil penelitian. Jenis penelitian ini bertujuan untuk melakukan identifikasi terhadap pengertian pokok atau dasar dalam hukum. Metode penelitian ini mengkaji mengenai pengaturan kaidah-kaidah dalam hukum positif. Jenis data yang dipergunakan dalam penelitian ini berupa Data Sekunder, yaitu data yang diperoleh dari Bahan Pustaka, seperti buku- buku, literatur, peraturan perundang-undangan, artikel, maupun arsip- arsip yang sesuai dengan penelitian yang akan dibahas, sumber Data Sekunder yang akan dibahas dalam penelitian ini.

\section{Hasil dan Pembahasan}

Salah satu kewenangan Bawaslu yang diberikan oleh undang-undang dalam menjalankan tugas pengawasan Pemilu adalah menyelesaikan sengketa Pemilu. Sengketa Pemilu dapat terjadi karena perbedaan penafsiran terhadap ketentuan peraturan perundang-undangan tentang Pemilu, yang bisa melibatkan peserta atau calon peserta Pemilu dengan penyelenggara Pemilu dalam hal ini KPU, dan antar peserta Pemilu. Selain itu sengketa juga bisa terjadi karena perbedaan pengertian dan pemahaman terhadap sesuatu peristiwa dalam proses Pemilu. Penyelesaian sengketa merupakan kewenangan yang dimiliki oleh Bawaslu. Setiap laporan atau temuan pelanggaran Pemilu yang bersifat sengketa Pemilu menjadi kewenangan Bawaslu 
untuk menyelesaikannya. ${ }^{55}$ Kewenangan penyelesaian sengketa itu diberikan kepada Bawaslu dalam menjalankan tugas pengawasannya. Dengan adanya kewenangan ini, maka terkait dengan sengketa Pemilu, peran Bawaslu tidak hanya sekedar memberikan rekomendasi atau meneruskannya kepada KPU, tetapi berwenang untuk memutuskan penyelesaian terhadap sengketa Pemilu tersebut.

Dari laporan atau temuan pelanggaran berupa sengketa Pemilu, akan ditangani sendiri oleh Bawaslu melalui tata cara penyelesaian sengketa Pemilu. Penyelesaian sengketa Pemilu pada Bawaslu dilakukan dengan mempertemukan kedua belah pihak yang bersengketa, yaitu Pemohon dan Termohon sebagai tindak lanjut dari laporan atau temuan tentang sengketa Pemilu. Terhadap laporan yang berupa permohonan penyelesaian sengketa yang masuk kepada Bawaslu dan diterima melalui Keputusan Pendahuluan, maka kemudian dilakukan Penyelesaian sengketa melalui musyawarah dengan mempertemukan para pihak yang bersengketa tersebut. Pengambilan keputusan penyelesaian sengketa dalam musyawarah adalah berdasarkan pendapat kedua belah pihak yang bersengketa yang kemudian diterima sebagai bentuk penyelesaian sengketa. Didalam proses musyawarah, kedua belah pihak mempunyai kesempatan yang sama untuk menyampaikan keterangan serta data dan bukti untuk menguatkan keterangannya Dari keterangan dan pandangan kedua belah pihak tersebutlah kemudian akan diambil keputusan yang terbaik oleh Bawaslu.

Apabila tidak tercapai kesepakatan dalam musyawarah, dimana pihak Pemohon dan Termohon tetap pada pendapatnya masing-masing, maka Bawaslu akan memberikan alternatif penyelesaian. Alternatif penyelesaian tersebut merupakan solusi terbaik yang diambil oleh Bawaslu berdasarkan keterangan atau pendapat para pihak. Apabila alternatif penyelesaian tersebut masih tetap tidak mencapai kesepakatan, maka Bawaslu akan mengambil keputusan untuk mengakhiri sengketa tersebut.58 Pengambilan keputusan penyelesaian sengketa dilakukan dalam Rapat Pleno pengambilan keputusan yang bersifat tertutup dan kemudian keputusannya disampaikan dalam rapat yang terbuka untuk umum. Keputusan yang diambil oleh Bawaslu dapat berupa keputusan yang mengabulkan permohonan Pemohon untuk seluruhnya atau sebagian dan keputusan menolak permohonan. Keputusan penyelesaian sengketa Pemilu tersebut kemudian disampaikan kepada Pemohon dan Termohon dalam penyelesaian sengketa Pemilu. Terhadap keputusan yang diambil ini, selain dari pada sengketa yang berkaitan dengan verifikasi partai politik peserta Pemilu dan sengketa penetapan daftar calon tetap anggota DPR, DPD, dan DPRD Provinsi dan DPRD Kabupaten/Kota, keputusan Bawaslu bersifat final dan mengikat.

Berkaitan dengan sengketa Pemilu tentang verifikasi partai politik peserta Pemilu dan sengketa tentang penetapan daftar calon tetap anggota DPR, DPD, dan DPRD Provinsi dan DPRD Kabupaten/Kota, keputusan Bawaslu bersifat tidak final dan tidak mengikat. Kepada pihak yang dirugikan kepentingannya dapat mengajukan gugatan kepada Pengadilan Tinggi Tata Usaha Negara. Dalam Pasal 259 Ayat (1) Undang-Undang Nomor 8 Tahun 2012 Tentang Pemilihan Umum anggota DPR, DPD, dan DPRD disebutkan bahwa "Keputusan Bawaslu mengenai penyelesaian sengketa Pemilu merupakan keputusan terakhir dan mengikat, kecuali keputusan terhadap sengketa Pemilu yang berkaitan dengan verifikasi partai politik peserta Pemilu dan daftar calon tetap anggota DPR, DPD, DPRD Provinsi, dan DPRD Kabupaten/Kota". Ketentuan pasal ini memberikan suatu pemahaman bahwa ada 2 (dua) sifat keputusan Bawaslu terkait dengan penyelesaian sengketa Pemilu. Pertama, keputusan Bawaslu bersifat final dan mengikat dalam penyelesaian sengketa Pemilu 
selain dari sengketa yang berkaitan dengan verifikasi partai politik peserta Pemilu dan sengketa daftar calon tetap anggota DPR, DPD, DPRD Provinsi, dan DPRD Kabupaten/Kota. Kedua, keputusan Bawaslu memiliki sifat tidak final dan tidak mengikat dalam penyelesaian sengketa verifikasi partai politik peserta Pemilu dan sengketa penetapan daftar calon tetap anggota DPR, DPD, DPRD Provinsi, dan DPRD Kabupaten/kota.

Sifat final dan mengikat keputusan Bawaslu dalam penyelesaian sengketa Pemilu berimplikasi kepada keharusan untuk melaksanakan keputusan tersebut. Akibat keputusan ini tidak ada upaya hukum lain lagi yang dapat dilakukan dan ditempuh oleh pihak yang merasa dirugikan, sehingga keputusan dalam bentuk ini telah memiliki kekuatan hukum untuk dilaksanakan. Adanya sifat final dan mengikat dalam penyelesaian sengketa ini memperlihatkan bahwa Bawaslu memiliki kewenangan mutlak terhadap penyelesaian sengketa. Sifat final dan mengikat keputusan Bawaslu ini dinilai cukup tepat jika dikaitkan dengan upaya mengakhiri sengketa yang terjadi ditengah suhu politik yang tinggi dan semakin meningkatnya persaingan dalam Pemilu. Banyaknya kepentingan politik peserta Pemilu akan menjadikan sengketa-sengketa akan bermunculan dan sulit untuk diselesaikan. Keadaan ini menunjukkan bahwa tugas penyelesaian sengketa bukanlah merupakan tugas yang ringan, sehingga untuk mengatasinya perlu suatu ketegasan dalam bentuk keputusan Bawaslu.

Keberadaan Bawaslu sebagai satu kesatuan fungsi penyelenggaraan Pemilu diyakini dapat membantu mengatasi permasalahan yang dapat menghambat penyelenggaraan Pemilu. Melalui keputusan yang bersifat final dan mengikat, maka diharapkan Bawaslu dapat mengakhiri sengketa Pemilu. Dengan demikian persoalan yang ada terkait dengan penyelenggaraan Pemilu bisa diselesaikan pada lembaga penyelenggara Pemilu itu sendiri. Keputusan Bawaslu yang bersifat final dan mengikat apabila dikaitkan dengan upaya untuk mengakhiri sengketa tidak menjadi suatu permasalahan yang perlu diperdebatkan karena undang-undang yang mengatur tentang Pemilu dan penyelenggaraan Pemilu telah mengaturnya dengan jelas. Persoalannya adalah tentang sifat keputusan final dan mengikat tersebut jika dikaitkan dengan tata cara atau mekanisme penyelesaiannya. Ketentuan tentang tata cara atau mekanisme penyelesaian sengketa pada Bawaslu adalah secara musyawarah atau dapat disebut sebagai Mediasi. Pada proses Mediasi, keputusan yang diambil oleh Mediator seharusnya tidak memiliki sifat final dan mengikat, tetapi hanya berupa kesepakatan antara dua pihak yang bersengketa saja.

Dalam proses Mediasi, penyelesaian hanya dapat dicapai apabila semua pihak yang bersengketa dapat menerima penyelesaian itu. Namun, apabila tidak tercapai kesepakatan, Mediator tidak bisa memaksakan keputusan yang dibuatnya kepada para pihak. Dengan demikian ketentuan tentang penyelesaian sengketa dalam undang-undang tentang Pemilu DPR, DPD, dan DPRD ini tidak konsisten memilih mekanisme penyelesaian sengketa pada Bawaslu. Meskipun demikian, hal tersebut dapat dimaklumi apabila kemudian keberadaan sifat keputusan Bawaslu tersebut dikaitkan dengan posisi Bawaslu sebagai satu kesatuan fungsi penyelenggaraan Pemilu. Dapat dipahami bahwa ketentuan tentang sifat final dan mengikat dari keputusan Bawaslu merupakan suatu bentuk dukungan terhadap perluasan dan penguatan tugas dan kewenangan Bawaslu dalam menjalankan tugas pengawasannya terhadap penyelenggaraan Pemilu.

Sifat keputusan Bawaslu berikutnya terhadap sengketa verifikasi partai politik peserta Pemilu dan sengketa penetapan daftar calon tetap anggota DPR, DPD, dan 
DPRD adalah tidak final dan tidak mengikat. Keputusan Bawaslu tidak mempunyai kekuatan hukum memaksa untuk dilaksanakan apabila pihak yang merasa dirugikan dari keputusan itu masih tidak menerima keputusan penyelesaian sengketa tersebut. Undang-undang masih memberikan kesempatan bagi para pihak untuk mengajukan gugatan ke Pengadilan Tinggi Tata Usaha Negara apabila sengketa tidak dapat diselesaikan melalui Bawaslu. Meskipun terhadap sengketa ini penyelesaian akhirnya melalui gugatan ke pengadilan, namun ketentuan Pasal 259 Ayat (2) menyebutkan bahwa mekanisme penyelesaiannya terlebih adalah melalui Bawaslu. Dari kedua sifat keputusan yang dimiliki oleh Bawaslu, yaitu sifat final dan mengikat serta adanya sifat keputusan tidak final dan tidak mengikat memperlihatkan bahwa Bawaslu memang menjalankan satu kesatuan fungsi penyelenggaraan Pemilu. Melalui sifat keputusan final dan mengikat, Bawaslu diharapkan dapat mengakhiri sengketa sehingga kemudian tidak menghambat jalannya proses Pemilu. Sifat keputusan dalam bentuk ini menjadikan permasalahan yang terjadi didalam penyelenggaraan Pemilu dapat diselesaikan pada lembaga penyelenggara Pemilu itu sendiri dan tidak sampai melibatkan lembaga lainnya.

Sementara itu, dengan tidak final dan tidak mengikatnya keputusan Bawaslu terhadap sengketa Pemilu yang berkaitan dengan hak konstitusional peserta Pemilu berupa sengketa verifikasi partai politik peserta Pemilu dan penetapan daftar calon tetap anggota DPR, DPD, dan DPRD memperlihatkan bahwa Bawaslu adalah lembaga penyelenggara Pemilu dan bukan badan peradilan yang berwenang menyelesaikan sengketa tentang hak konstitusional seseorang untuk ikut memilih dan dipilih dalam Pemilu. Sebagai lembaga penyelenggara Pemilu, Bawaslu memiliki tanggung jawab menjaga agar penyelenggaraan Pemilu dapat berjalan sesuai dengan aturannya. Sehingga setiap permasalahan terutama sengketa Pemilu dapat diselesaikan dan tidak mengganggu pelaksanaan Pemilu serta tidak mengurangi nilai dan upaya pencapaian tujuan Pemilu tersebut.

Sifat keputusan tidak final dan tidak mengikat jika dikaitkan dengan tata cara atau mekanisme penyelesaiannya akan lebih tepat untuk disebut sebagai bentuk penyelesaian sengketa secara musyawarah atau Mediasi. Karena dalam proses Mediasi memang tidak ada keterikatan dari para pihak untuk harus mengikuti apa yang diputuskan oleh Mediator. Sifat tidak final dan tidak mengikat keputusan Bawaslu menunjukkan bahwa Bawaslu menjalankan peran sebagai Mediator sengketa Pemilu. Apabila para pihak dapat menerima upaya penyelesaian sengketa yang diselesaikan melalui musyawarah atau Mediasi di Bawaslu, maka sengketa akan selesai dan akan menjadi keputusan yang akan dilaksanakan. Namun, jika tidak dapat diselesaikan maka ada upaya hukum berikutnya yang bisa dilakukan oleh pihak yang dirugikan.

\section{Penutup}

Dalam penyelesaian sengketa Pemilu terdapat dua sifat keputusan Bawaslu, yaitu keputusan yang bersifat final dan mengikat serta keputusan yang bersifat tidak final dan tidak mengikat. Sifat keputusan final dan mengikat berlaku terhadap semua sengketa Pemilu yang tidak berkaitan dengan sengketa verifikasi partai politik peserta Pemilu dan penetapan daftar calon tetap anggota DPR, DPR, dan DPRD. Sifat keputusan dalam bentuk ini dilakukan dalam rangka mengakhiri sengketa, sehingga sengketa yang terjadi tidak berkepanjangan dan mengganggu pelaksanaan Pemilu. Keputusan Bawaslu bersifat tidak final dan tidak mengikat terhadap sengketa verifikasi partai politik peserta Pemilu dan penetapan daftar 
calon tetap anggota DPR, DPD, dan DPRD sehingga memberikan kesempatan bagi pihak yang merasa dirugikan untuk melakukan gugatan kepada Pengadilan Tinggi Tata Usaha Negara.

\section{Daftar Pustaka}

Dahlan Thaib, 1993, Implementasi Sistem Ketatanegaraan Menurut UUD 1945, Liberty, Yogyakarta.

Didik Sukriono, Menggagas Sistem Pemilihan Umum, Jurnal Konstitusi PKK Universitas Kanjuruhan Malang Volume II Nomor 1 Juni 2009.

Didik Supriyanto, Dkk, 2012, Penguatan Bawaslu ; Optimalisasi Posisi, Organisasi, dan Fungsi Dalam Pemilu 2014, Perludem, Jakarta.

Firmanzah, 2010, Persaingan, Legitimasi Kekuasaan, dan Marketing PolitikPembelajaran Politik Pemilu, Ed.1, Yayasan Pustaka Obor Indonesia, Jakarta.

Idul Rishan, 2013, Komisi Yudisial Suatu Upaya Mewujudkan Wibawa Peradilan, Genta Press, Yogyakarta.

Janedjri M. Gaffar, 2012, Politik Hukum Pemilu, Konstitusi Press, Jakarta.

Jimly Asshiddiqie, 2009, Pengantar Ilmu Hukum Tata Negara, PT.RajaGrafindo Persada, Jakarta , 2012, Perkembangan dan Konsolidasi Lembaga Negara Pasca Reformasi, Ed.2, Cet.2, Sinar Grafika, Jakarta. 2013, Menegakkan Etika Penyelenggara Pemilu, PT.RajaGrafindo Persada, Jakarta.

Jojo J Prihatmoko, 2003, Pemilu 2004 dan Konsolidasi Demokrasi, LP2I Press, Semarang.

Khairul Fahmi, 2012, Pemilihan Umum \& Kedaulatan Rakyat, Ed.1 Cet.2, PT. RajaGrafindo Persada, Jakarta.

Ni'matul Huda, 2013, Hukum Tata Negara Indonesia, Edisi Revisi, Cet. 8, PT.RajaGrafindo Persada, Jakarta. , 2009, Hukum Pemerintahan Daerah, Nusa Media, Bandung.

Nur Hidayat Sardini, 2011, Restorasi Penyelenggaraan Pemilu Di Indonesia, Fajar Media Press, Yogyakarta.

Soehino, 2010, Hukum Tata Negara, Perkembangan Pengaturan Dan Peleksanaan Pemilihan Umum Di Indonesia, Edisi Pertama, BPFE-Yogyakarta, Yogyakarta.

Soerjono Soekanto, 1986, PengantarPenelitian Hukum,Cet.3, PT. RajaGrafindo Persada, Jakarta.

Soerjono Soekanto \& Sri Mamudji, 2010, Penelitian Hukum Normatif : Suatu Tinjauan Singkat, Ed.1, Cet.12, Rajawali Pers, Jakarta.

Topo Santoso \& Didik Supriyanto, 2004, Mengawasi Pemilu Mengawal Demokrasi, PT.RajaGrafindo Persada, Jakarta.

Takdir Rahmadi, 2011, Mediasi : Penyelesaian Sengketa Melalui Pendekatan Mufakat, PT.RajaGrafindo Persada, Jakarta.

YW Sunindhia, 1996, Praktek Penyelenggaraan Pemerintahan di Daerah, Rineka Cipta, Jakarta. 